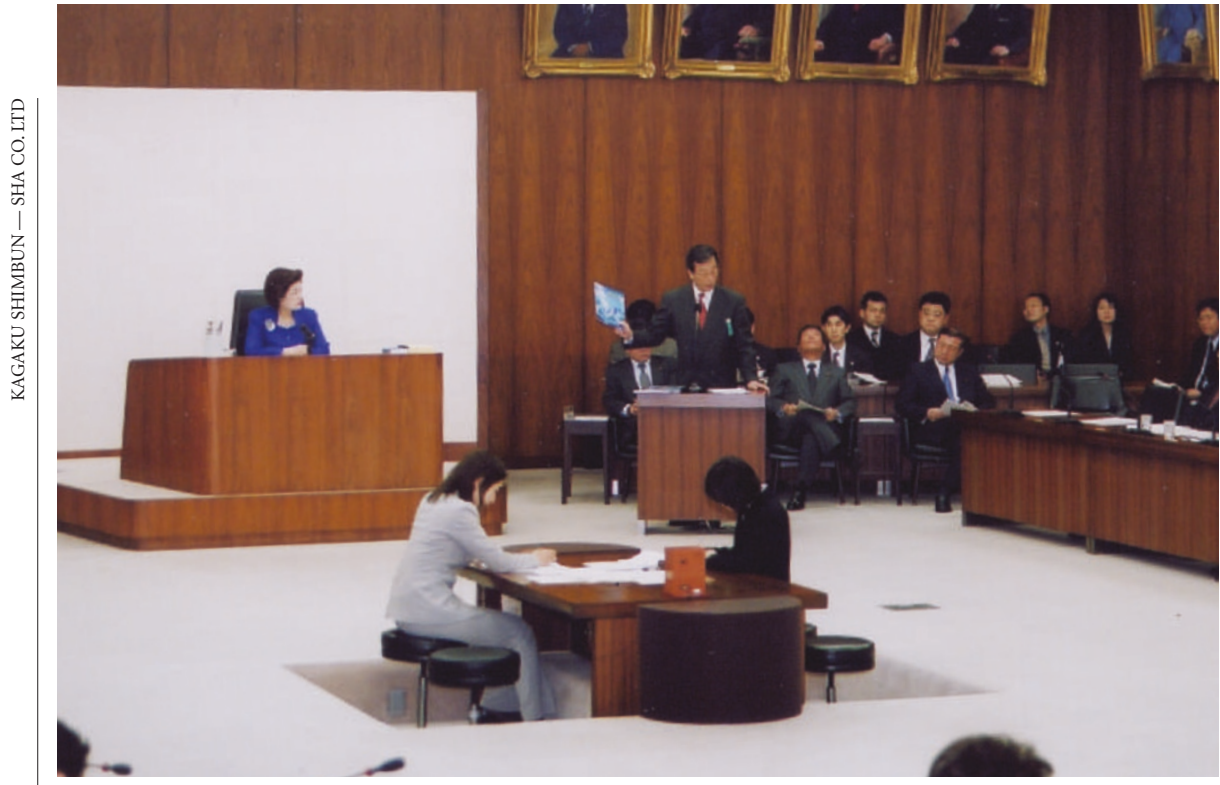

Kiyoshi Kurokawa (standing) wants Japan to implement its own version of the US National Academies.

\section{Japan shakes up council to offer scientists political clout}

David Cyranoski, Tokyo

Don't hold your breath — but Japanese scientists may be on the verge of getting a strong voice in their nation's policy-making.

At a parliamentary committee hearing on 19 March, the country's minister of science and technology and the president of the Science Council of Japan (SCJ) proposed moving the currently ineffectual council which represents some 760,000 scientists from 1,481 academic societies - from the ministry of home affairs to the prime minister's office.

SCJ president Kiyoshi Kurokawa claims that the transfer could put the council on a par with the US National Academies, which advise the government on many topics related to science, medicine and engineering.

This would give the council the status it was intended to have, advocates of the change say. Since its foundation in 1949, the SCJ has reported to the government on issues from mad cow disease to scientific misconduct. But with some exceptions, its advice has been ignored, says Kurokawa. Ministries instead took advice from their scientific committees, he says.

"The SCJ has always been an advisory body - now it would be a real one," the SCJ's executive director, Masatsugu Yoshida, commented at the hearing.

Kurokawa says that central government needs a voice that is not compromised by ministerial affiliation. The existing advisory committees are "a protective mechanism for bureaucrats when policies fail", he says.

But whether the promised influence and independence will materialize remains to be seen. Yukio Hatoyama, a prominent representative of the opposition Democratic Party, agrees that the council should be reformed.
"The purpose of the council isn't clear to the people," he told the hearing. "It has a meagre existence." Hatoyama remains unconvinced that the proposed reforms will enable the council to give independent advice on sensitive topics, as it will be attached to the prime minister's office and reliant on it for funding and administrative support.

Toshimitsu Motegi, the science minister, argued that the reformed council would be independent. Kurokawa added that the body would be transparent in all of its functions and would post its reports on the Internet.

Under the proposal, the SCJ would work with the Council for Science and Technology Policy (CSTP), the country's top science policy-making body. But the CSTP has been criticized as being out of touch with science. Its 15 members include the prime minister, six ministers of state, and eight private citizens appointed by the government, few of whom are working researchers.

The proposal also seeks to allow the SCJ's 210 members to elect new members directly. The current method - taking people recommended by member societies — creates an environment where members are seen as representing their society's interests, says Kurokawa. The council's seven existing divisions would be combined into three: human and social sciences; life sciences; and physical sciences and engineering.

The diet's lower house will meet again this week and is expected to approve the proposal and pass it on to the upper house. It is likely to become law in April. In preparation for the SCJ's beefed-up role, Kurokawa is setting up a joint committee with the US National Academies to look at topics related to national security.
Sellafield seeks solid foundation for cleaner wastewater

Laura Nelson, London

Persistent discharges of radioactive waste into the Irish Sea could come to an end thanks to a technique that can lift an awkward pollutant out of water.

Chemists at the Sellafield reprocessing plant in northwest England have tested a process aimed at removing technetium-99 from wastewater.

Technetium-99 has a half-life of 213,000 years and is the main radionuclide still being discharged from Sellafield. It has been accumulating in seaweed and lobsters as far afield as the North Sea, leading to angry protests from the Norwegian and Irish governments.

Most of Sellafield's technetium-99 was generated by a now-disused processing plant, and some $1,800 \mathrm{~m}^{3}$ of contaminated wastewater is stored in tanks at the site. The isotope had proved awkward to extract and so the water, once cleaned of other pollutants, is being dumped into the sea at a rate of about $240 \mathrm{~m}^{3}$ per year.

The new cleaning process uses the salt tetraphenylphosphonium bromide (TPP), which is added to the wastewater. TPP binds with technetium-99 to form an insoluble compound that precipitates out as a solid.

The Sellafield chemists completed tests on the technique in December and will release their evaluation in April. If the results are positive - as many observers expect - BNFL, which operates the plant, is set to implement the technology at a cost of $\mathfrak{E} 2$ million (US\$3.7 million).

"The results are very promising but we still have to go through a final assessment," says Ian Parker, head of nuclear regulation at the UK Environment Agency, which oversees the plant.

Parker adds that the agency had been worried that the precipitate might have been difficult to incorporate in concrete for safe and permanent disposal, but that early test results suggest this can be done.

Technetium-99 is not thought to be harmful in small doses, but Ireland and Norway have complained that traces of the isotope found in marine life have led to cuts in the prices fish merchants will pay for lobsters and other seafood.

The abatement technology could ease a major headache for BNFL, but other problems remain at Sellafield. European courts, for example, have been hearing a plea from the Irish government for the facility to close its mixed oxide fuel plant, which releases small amounts of plutonium into the sea. 